\title{
Bell hooksin vapauttava kasvatus vie hiljaisen tiedon äärelle
}

\author{
bell hooks (2010). Teaching Critical Thinking: \\ Practical Wisdom New York: Routledge. 191 sivua
}

BELL HOOKSIN vapauttavasta kasvatuksesta voi nyt lukea kirjatrilogiasta, sillä viime vuonna julkaistiin sarjan viimeinen teos Teaching Critical Thinking: Practical Wisdom. Nimensä mukaisesti siinä käsitellään vapauttavan kasvatuksen ajatusten soveltamista käytännön opetustyössä. Kokoelma sisältää 32 esseetä, jotka perustuvat opiskelijoiden ja opettajien hooksille osoittamiin kysymyksiin hänen kasvatusajattelunsa toteutuksesta.

Bell hooksin vapauttavan kasvatuksen ydinajatuksena on, että koulutuksen tulee toimia vapauttajana eikä yhteiskuntaan sopeuttajana. Tämä edellyttää totuttujen ajattelutapojen ja rajojen rikkomista. Bell hooks on selvimmin avannut kasvatusoppejaan teoksessaan Teaching to Transgress: Education as the Practice of Freedom (1994), joka on suomennettu nimellä Vapauttava kasvatus (Kansanvalistusseura 2007). Hän palasi vapauttavan kasvatuksen teemoihin teokzsessaan Teaching Community: A Pedagogy of Hope (2003), jossa samoin kuin nyt julkaistussa teoksessa hänen aiemmin esittämänsä teemat kertautuvat monella tavoin.

Bell hooks on kehitellyt kasvatusajatteluaan yliopistomaailmassa. Teaching Community teok- sessa vapauttavan kasvatuksen ideat laajenevat entistä selvemmin luokkahuoneen ulkopuolelle: tasa-arvoisia oppimisyhteisöjä voidaan luoda muuallakin kuin koulutuksessa - ne voivat toimia erilaisissa paikoissa, joissa ihmiset kokoontuvat jakamaan ajatuksiaan. Hooks käsittelee aiempaa painokkaammin demokraattisuuden lisäämistä tavoittelevan pedagogiikan ja yhteiskunnan suhteita samoin kuin sosiaalisen muutoksen mahdollisuuksia. Hän puhuu kasvatukseen kuuluvasta välittämisestä ja korostaa Paulo Freiren tavoin toivon luomista paremman tulevaisuuden saavuttamiseksi.

VALTARAKENTEIDEN TUTKIJA, FEMINISTI, PEDAGOGI

Bell hooks on feministisen pedagogiikan vaikuttavimpia persoonia. Hän on feministi ja kulttuurintutkija, jonka tutkimuksellinen mielenkiinto kohdistuu erityisesti sosiaalisten voimien aikaansaamiin erotteluihin ihmisten välillä. Mittavalla kirjallisella tuotannollaan hän tähtää muun muassa sukupuolta, luokkaa, etnisyyttä ja "rotua" koskevien valtarakenteiden purkamiseen. Bell hooksin radikaalin kasvatusajattelun pontimina ovat toimineet hänen omat kokemuksensa ja niiden teoretisointi. 1990-luvulta lähtien hänen kirjoitustapansa kytkeytyy kulttuurintutkimuksen omaelämäkerralliseen käänteeseen, jossa elämäntarinat ja tutkijan oma elämänhistoria ovat nousseet teoretisoinnin kohteiksi. Hänen näkemyksensä mukaan henkilökohtainen on paitsi yhteiskunnallista myös teoreettista.

\section{KRIITTISEN TEORIAN} MAASTOSSA

Bell hooksin kasvatusajattelun on katsottu selvimmin sijoittuvan kriittisen teorian alueelle. Erityisesti freireläisen kasvatusajattelun keskeinen asema tulee monin tavoin esiin hooksin pedagogiikassa. Sen lisäksi kriittisellä feministisellä pedagogiikalla on tärkeä merkitys hänen teoretisoinneissaan. Monista yhteisistä lähtökohdista huolimatta hooks on kritisoinut

paitsi valtavirran kasvatusajattelua, myös kriittistä ja feminististä pedagogiikkaa. Valtavirran pedagogiikkaa hän moittii liiallisesta järkikeskeisyydestä ja hierarkkisuudesta, kriittistä pedagogiikkaa konkreettisuuden puutteesta.

Hooksin mielestä vapauttava kasvatus ylittää paitsi kriittisen myös feministisen pedagogiikan, sillä se korostaa hyvinvointia: kyse on kokonaisvaltaisesta henkisestä 


\section{एैy}

kasvusta. Se edellyttää opettajalta aitoa kutsumusta ja sitoutumista opiskelijoiden hyvinvoinnin lisäämiseen ja itseksi kasvun tukemiseen. Hooks haluaa purkaa opetuksessa vakiintuneen dikotomisen jaon mieleen ja ruumiiseen painottaen mielen, ruumiin ja hengen kokonaisuutta.

Hooksin teosten kanssa voi asettautua mukavasti nojatuoliin ja kuunnella hänen soljuvaa tarinointiaan, joka ilmentää hänen yhteyksiään afrikkalaisamerikkalaisiin naisvaikuttajiin ja kerrontaperinteeseen. Tarinointi on elävää ja teksti haastaa omakohtaiseen pohdintaan. Tosin lukukokemus voi ärsyttää niitä, jotka ovat tottuneet perinteiseen tieteelliseen teoretisointiin.

Bell hooksia voi pitää postmodernina paitsi ajattelultaan myös ilmaisutavaltaan, jota leimaa kiinnostus performatiivisuuteen, kielelliseen leikittelyyn ja teoreettisiin kollaaseihin. Hooks itse on korostanut, että kirjoittajana hän haluaa ilmaisemisen vapautta, luoda tiloja kriittiselle ajattelulle ja kokeilla erilaisia kirjoittamisen tyylilajeja. Hänen tuotantonsa on 2000-luvulla muuttunut yhä esseistisempään suuntaan ja hän on halunnut suunnata tekstinsä akateemista yhteisöä laajemmalle yleisölle. Tässä trilogian viimeisessä teoksessa hooksin ilmaisu on irtautunut yhä selvemmin akateemisesta kirjoittamisesta ja hän tähtää viestinsä selvästi kasvatusalan käytännön toimijoille.

\section{AITO OSALLISTAVA PEDAGOGIIKKA VASTAVUOROISTA}

Bell hooksin radikaalin kasvatusajattelun perustana ovat hänen yhteiskuntateoreettiset näkemyksensä, joiden pohjalta hän kritisoi koulutuksen keskiluokkaista valtakulttuuria rodun, sukupuolen ja luokan näkökulmista. Yhteiskunnan erilaisista syrjäyttävistä käytännöistä irtautuminen edellyttää hooksin mielestä valtahierarkioiden ja totuttujen ajattelutapojen tiedostamista ja toimimista uudella tavalla. Osallistavassa pedagogiikassa opetus ymmärretään opettajan ja opiskelijoiden yhteistyöksi. Aito osallistuminen edellyttää hooksin mukaan vastavuoroista oppimista, jossa opettaja ja opiskelijat sitoutuvat toimimaan uudenlaisissa rooleissa kriittisen oppimisen edellytysten parantamiseksi.

Bell hooksin mukaan yhteiskunnallisia valtahierarkioita ja epätasa-arvoa voidaan purkaa opetustilanteita demokratisoimalla. Tasa-arvoisen oppimisyhteisön luominen ja opetuksen vuorovaikutuksellisuus edellyttävät koulutuksessa vallitsevan rationaalisuutta painottavan ihmiskäsityksen laajentamista. Hän puhuu opetukseen kuuluvasta intohimosta, tunteista ja henkisestä hyvinvoinnista. Juuri koulutuksen ihmiskäsityksen kritiikki ja vaatimus ihmisen kokonaisvaltaisena kohtaamises- ta tekevät hooksin kasvatusajatuksista innostavia mutta niihin sisältyvät myös opettamisen ehkä merkittävimmät haasteet. Opetuskulttuuriin omaksuttu järkikeskeinen toimintamalli elää lujassa niin opettajien kuin opiskelijoidenkin mielissä.

Hooksin teksteissä toistuvaa kritiikkiä saavat perinteinen tiedonjako-opettaminen ja asiakeskeisen innottomat opettajat. Hänen mielestään suuri osa opettajista ei ole kriittisiä ajattelijoita eikä hän vaikuta toiveikkaalta, että heistä sellaisia tulisikaan. Yleensä ei ajatella, että yliopistossa kenenkään sanomisia sensuroidaan, mutta hooks pitää tiedonjakoopettamista myös vaientamisena, "alistajakulttuurina”. Tämä raju kritiikki kytkeytyy ehkä osin hooksin turhautumiseen taistelussa opetuskulttuurin muuttamiseksi.

Toisaalta hän myöntää, että opettajia voi myös pelottaa antautuminen avoimeen vuorovaikutukseen ja tunteiden kohtaamiseen. Tässä kohden voi heittää haasteen opettajakoulutukselle, jossa myös hooksin mukaan pitäisi antaa eväitä itsetuntemuksen ja itsetunnon lisäämiseen.

\section{OPETTAJAN HILJAINEN TIETO ESIIN}

Opettamiseen kuuluvan hiljaisen tiedon esiin nostamista voi pitää hooksin kasvatusajattelun merkittävänä ansiona. On asioita, joista koulutuskulttuuris- 


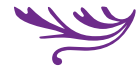

sa ei puhuta ja joita ylipäätään on vaikea pukea sanoiksi. Kun hooks puhuu itsetunnosta, henkisyydestä, rakkaudesta, ruumiillisuudesta tai kosketuksen voimasta, se todennäköisesti ärsyttääkin monia opettajia. Asiakeskeiseen opetuskulttuuriin mukautuminen ja opiskelijoista etäällä pysyminen houkuttaa, kun omien tunteiden kanssakin voi olla vaikea tulla toimeen. Tosiasia kuitenkin on, että tunteiden kohtaamiselta opetuksessa ei voi kokonaan välttyä, vaikka niiltä pyrkisi sulkemaan silmänsä. Hooks puhuu esimerkiksi yliopistoon tulevista opiskelijoista, joista useilla on jo lapsuudesta juontavia itsetunnon ongelmia. He joutuvat painiskelemaan niiden kanssa opiskellessaan ja ne usein tavalla tai toisella haittaavat oppimista samoin kuin vuorovaikutustilanteita. Niin ikään hooks käsittelee integriteettiä, joka opetuksen tavoitteisiin parhaimmillaan voisi kuulua.

Bell hooks saa yhteiskunnalliseen muutokseen pyrkivän opettamisen kuulostamaan helpolta huolimatta siitä, että hän käsittelee teksteissään tällaiseen opettamiseen liittyviä pulmia ja kertoo myös vastustuksesta jota on itsekin emansipoimaan pyrkivänä opettajana kohdannut. Teksteistä saa kuvan, että hooks on oppinut ratkomaan kypsällä tavalla vuorovaikutuksen ongelmat ja kohtamaan empaattisesti opiskelijoiden vaikeudet. Tosin hän - meidän tavallisten opettajien helpotukseksi - myöntää, että yliopisto-opettajan alkutaipaleella hänkin oli usein neuvoton pyrkiessään luomaan tasa-arvoista oppimisyhteisöä.

\section{DIALOGINEN OPETUSTAPA TÖRMÄÄ VALTAKYSYMYKSIIN}

Olen omassa opetuksessani soveltanut hooksin osallistavaa pedagogiikkaa ja ilman muuta kannatan dialogista opetustapaa, mutta helppoa tai yksinkertaista se ei aina ole. Yhteiskunnallisten valtahierarkioiden tiedostaminen nostattaa joissakin opiskelijoissa vastustusta, koska se horjuttaa liiaksi heidän viatonta käsitystään maailmasta. Vaikka hooks puhuu paljon vallan ja vastuun jakamisesta opiskelijoiden kanssa ja opettajan ja opiskelijoiden suhteesta, hän kiinnittää yllättävän vähän huomiota opiskelijoiden keskinäisiin suhteisiin ja niihin liittyviin valtapositioihin, joiden itse koen lisäävän dialogin haasteellisuutta. Myös useat muut kriittiset ja feministipedagogit ovat osoittaneet ryhmän muodostavan valtasuhteiden verkoston, joka pistää dialogiin pyrkivän opettajan lujille.

Bell hooks on noussut maailmanmaineeseen kriitikkona ja toisin toimijana: hän on ylittänyt rajoja teoreetikkona, kirjoittajana ja opettajana. Hän on karismaattinen ja innostaa muitakin opettajia rajojen ylityksiin. Hän teksteis- tään käy kuitenkin esiin, että vastavirtaan kulkijana ja kriitikkona akateemisessa maailmassa ei ole ollut helppoa. Hän kertoo väsymyksestään ja turhautumisestaan värillisenä toisinajattelijana ja emansipoimaan pyrkivänä opettajana yritysmäisesti johdetussa yliopistossa. Hänen uravalintansa ovat johtaneet hänet huippuyliopistoista aina vain kauemmas formaalista koulutuksesta.

Esseekokoelmaa voi lukea missä järjestyksessä tahansa tai poimia vain itseä kiinnostavimmat aiheet. Vaikka tässä trilogian viimeisessä osassa käsitellään vapauttavan kasvatuksen ydinajatuksia, niihin syvällisempi perehtyminen edellyttää ensimmäisen osan lukemista. Esseet voivat toimia myös opettajan oman havainnoinnin tukena, sillä niissä tehdään näkyväksi opetusryhmien ohjaamiseen liittyvää hiljaista tietoa, josta on vaikea puhua ja jakaa muiden kanssa.

Marjo Vuorikoski

$K T$, lehtori, kasvatustieteen laitos, Tampereen yliopisto 